\title{
ЕТАПИ СТВОРЕННЯ МОДУЛЯ АВТОМАТИЗОВАНОЇ СИСТЕМИ ПІДТРИМКИ НАУКОВИХ ДОСЛІДЖЕНЬ ПРИ ПІДГОТОВЦІ ЕКОЛОГІВ
}

\footnotetext{
У статті обтрунтовано необхідність розробки $і$ застосування модулів автоматизованих систем підтримки наукових досліджень при підготовці екологів. Наведено варіант реалізації модуля такої системи при визначенні якості води. Відзначено особливості побудови иього модуля з використанням програмного пакету MathCAD.

Ключові слова: підготовка фахівців, науково-дослідна робота, інформачійні технології, екологія, якість води, автоматизовані системи підтримки наукових досліджень.
}

В статье обоснована необходимость применения автоматизированных систем поддержки научных исследований при подготовке экологов. Приведен вариант реализации модуля такой системы при определении качества воды. Отмечень особенности построения модуля с использованием програмного пакета МаthCAD.

Ключевые слова: подготовка спечиалистов, научно-исследовательская работа, информачионные технологии, экология, качество воды, автоматизированные системы поддержки научных исследований.

The necessity of development and application modules of automated support systems research in the preparation of environmentalists. An option of the module of the system to determine water quality. Noted features of this module using the software package MathCAD.

Key words: training, research work, information technology, ecology, water quality, automated support systems research.

Споживацьке ставлення суспільства до природних ресурсів поставили планету на межу екологічної кризи. Забруднення та деградація навколишнього середовища негативно впливає на стан здоров’я, тривалість життя і благополуччя людей. Сучасне суспільство потребує формування нового менталітету та типу суспільної свідомості, в основі якого - сталий екологічний розвиток. Тому підготовка фахівців-екологів є першочерговою потребою будь-якої сучасної держави.

На сьогодні не викликає сумнівів той факт, що сучасне природознавство, в рамках якого виникла $і$ розвивається екологічна парадигма, не може існувати і розвиватися без широкого застосування інформаційних технологій із застосуванням математичного апарату. Це зумовлено тим, що екологічні дослідження не можуть здійснюватися лише з описових позицій, а вимагають виявлення об'єктивних кількісних і структурних характеристик досліджуваних явищ, що дозволяє виокремити 3 величезного набору розрізнених і часто суперечливих даних важливі 3 природоохоронної позиції параметри $\mathrm{i}$ змінні.

Ця обставина врахована у процесі формування навчальних планів підготовки екологів через включення до них таких дисциплін: «Інформаційні технології», «Математичне моделювання та прогнозування стану довкілля», «Інформатика та системологія». Основною сутністю підготовки екологів за цим циклом дисциплін є набуття знань і вмінь, необхідних для постановки і розв'язання як завдань 3 прикладним змістом, так і напрацювання досвіду застосування цих знань в ситуаціях, що мають місце в екологічній практиці. Проте під час вивчення зазначених дисциплін часто вивчаються $і$ застосовуються стандартні ситуації, без змістовного осмислення, без актуалізації взаємозв'язків курсів 3 циклом спеціальних дисциплін, що, у свою чергу, сприяє зниженню мотивації у майбутніх екологів до творчого мислення і пошуку обгрунтованих рішень. Проте активне залучення студентів до науково-дослідної роботи може сприяти усуненню зазначених недоліків навчального процесу.

Одним із напрямів підвищення якості фахових знань, розвитку творчого мислення є розроблення модулів автоматизованих систем підтримки наукових досліджень (АСПНД), які спрямовані на інформаційне забезпечення студентів у розв'язанні фахових завдань. Застосування таких модулів у змісті окремих навчальних курсів, а також під час проведення науково-дослідної роботи дозволить майбутнім екологам значно розширити можливості щодо опанування методів оптимального вирішення фахових задач.

Розробленням та застосуванням автоматизованих систем підтримки наукових досліджень опікується значна кількість науковців. Зокрема, визначенням ефективності застосування таких систем у навчальному процесі та науково-дослідній роботі студентів займалися С. Гаврилов, О. Жиганов, Г. Лісьєв, І. Семенова [2; 3], розробленні окремих модулів і вимог до АСПНД присвячено дослідження В. Ізмайлова, С. Кіпрушкіна, С. Курскова, М. Озерової, Н. Фомічова, А. Хахаєва [4; 5]. Проте зазначені дослідження сконцентровані на використанні таких систем у підготовці фахівців у галузі соціології, економіки, фізики. Задля визначення підходів до розроблення і використання модулів автоматизованої системи підтримки наукових досліджень у підготовці екологів необхідно здійснити аналіз змісту підготовки фахівців, рівня застосування інформаційних технологій та математичних методів у фахових методах і методиках, визначити актуальні напрями дослідження в екології. 
Meта статmi - визначити принципи створення та використання окремих модулів автоматизованих систем підтримки студентських наукових досліджень в галузі екології.

Екологічний моніторинг навколишнього середовища є одним із пріоритетних завдань державної політики в галузі екології. При цьому, особлива увага приділяється якості питної води, особливо у сільських населених пунктах. Як правило, екологічний моніторинг джерел водопостачання супроводжується накопиченням і обробленням значних масивів даних, які потребують аналітичного підходу. Оцінювання якості питної води є одним 3 основних фахових завдань еколога та темою багатьох наукових досліджень, учасниками яких $є$ і студенти. Однак при цьому такі дослідження пов'язані зі значною кількістю показників, за якими здійснюється оцінювання, складністю стандартизованої процедури оцінювання, що потребує значних витрат часу, відповідної підготовки персоналу і не усуває ймовірності припущення помилок, пов'язаних їз людським фактором.

Складність і тривалість проведення процедур оцінювання стану екологічних об'єктів, а також процесу прийняття адекватного одержаним результатам розв'язку зумовлює потребу в їх автоматизації. У першу чергу для цього необхідно застосовувати автоматизовані системи підтримки наукових досліджень [2].

Для розв'язання екологічних завдань на основі автоматизованих систем використовується множина різноманітних методів і алгоритмів. Одним із основних методів, покладених в основу побудови автоматизованих систем, є метод класифікації.

Ураховуючи те, що екологічні системи, які складаються зі значної кількості взаємопов'язаних між собою елементів, є типовим прикладом складних систем, для їх опису, зазвичай, застосовують формальні моделі, в тому числі і мовні, побудова яких потребує наявності формальних мов опису. Кожна 3 таких мов виконує функції класифікації об'єкта, яка полягає у визначенні специфічного набору його ознак. У загальному сенсі класифікація об'єктів передбачає перетворення вхідної інформації, в якості якої розглядаються певні параметри та ознаки образів, у вихідну, на основі якої здійснюється висновок про те, до якого класу відноситься образ (об’єкт), що підлягав розпізнаванню.

Процес класифікації здійснюють у два етапи: на першому розробляють класифікатор, на другому - визначають стан об'єкта за допомогою певного класифікатора.

Етапи процесу класифікації схематично представлені на рисунку 1.

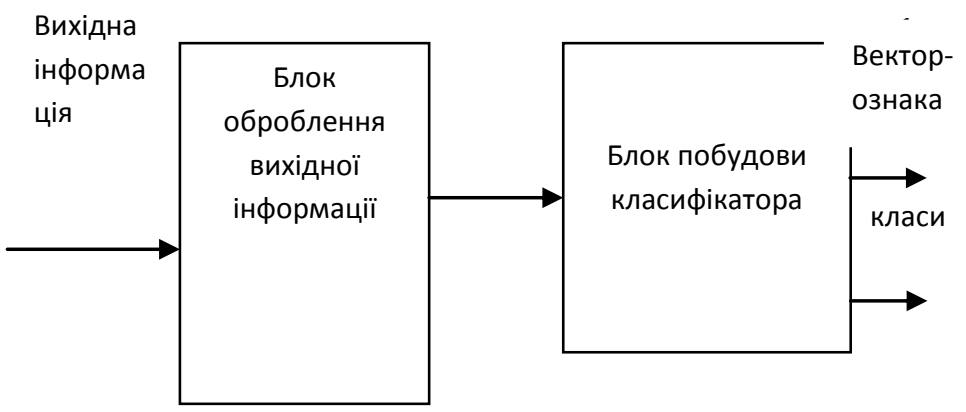

Рис. 1. Етапи процесу класифікаиіi

Розроблення класифікатора передбачає подання на вхід блоку оброблення вихідної інформації множини ознак об'єкта, якими можуть бути, наприклад, покази вимірювальної апаратури, результати аналізів тощо. При цьому, число ознак об'єкта може бути достатньо велике, що потребує значних апаратних та програмних ресурсів системи для їх оброблення. Функціями такого блоку є визначення інформаційної значущості ознак, виявлення взаємозалежності між ними, відхилення ознак, які не мають суттєвого значення.

До основних функцій першого етапу можна віднести: уведення та оброблення вихідної інформації, формалізацію ознак, розроблення алгоритму класифікації, визначення станів, яких може набувати об'єкт, аналіз якості роботи класифікатора.

На другому етапі вектор-ознака подається на вхід класифікатора, який на підставі цих даних за певним алгоритмом визначає клас, до якого належить об’єкт, що розпізнається. Варто зазначити, що алгоритм визначення об'єкта 3 допомогою класифікатора відрізняється від алгоритму розроблення класифікатора. При цьому перший визначає структуру класифікатора, а другий - пошук альтернативних варіантів структури.

Основними функціями другого етапу є оброблення вихідної інформації в реальному часі та визначення стану об'єкта, який класифікують, на підставі ознак за спеціальним алгоритмом.

Реалізація першого етапу може займати значну кількість часу і потребувати знань експертів у різних галузях. На цьому етапі першочерговими $є$ питання ефективності роботи класифікатора. На другому етапі використовується готовий класифікатор, який у реальному часі повинен визначати клас динамічного об'єкта. При цьому важливим є не тільки ефективність визначення класу об'єкта, а й швидкодія класифікатора. 
Виходячи $з$ основних аспектів методу класифікації та принципів розроблення АСПНД [6; 7], розглянемо технологію побудови одного з іiі модулів для визначення якості води, який успішно використовується у проведенні наукових досліджень майбутніми екологами в Національному університеті біоресурсів і природокористування України. Зокрема, програмну реалізацію такого модуля, методику його застосування, аналіз отриманих результатів студенти екологи опановують у розрізі вивчення дисципліни «Інформаційні технології». Практичне застосування модуля здійснено студентами під час проведення наукових досліджень у рамках держбюджетних тематик «Розробка інформаційно-аналітичного комплексу оцінки якості води для потреб сільського господарства» та «Розробка методики інформаційно-статистичного аналізу i моделювання стану джерел сільськогосподарського водопостачання».

Як програмне середовище для побудови модуля автоматизованої системи підтримки наукових досліджень задля визначення якості води було використано пакет із класу систем автоматизованого проектування MathCAD фірми Mathsoft.

Відповідно, до чинної нормативної документації [8] у визначенні якості поверхневих вод України, які використовуються в джерелах централізованого питного водопостачання, за гігієнічними та екологічними критеріями використовується 80 показників, які розподілені на 7 окремих груп (блоків). Для кожного показника визначено діапазони значень, що відповідають чотирьом класам якості. Оцінювання якості води може здійснюватися за трьома стандартизованими методичними підходами: значеннями окремих показників, інтегральними блоковими індексами та інтегральним комплексним індексом.

На першому етапі створення модуля АСПНД було здійснено розроблення класифікаторів для кожного показника окремо, причому класифікатори відрізняються, як межами класів, так і типами (для класів, заданих одним, або двома інтервалами). Це пов’язано 3 тим, що стандартизована процедура визначення якості води передбачає визначення класу якості до якого належить конкретне значення певного показника. Для кожного показника встановлено 4 класи якості, межі яких $є$ наперед визначеними. Особливість полягає в тому, що для деяких показників межі класів якості задані одним інтервалом (наприклад, мінералізація, хлориди, жорсткість тощо), а для деяких - двома (наприклад, водневий показник, насичення води киснем).

Для розробки класифікатора в середовищі MathCAD використовувалися вбудовані програмифункції за допомогою яких був реалізований алгоритм класифікації [1]. Класифікатори розроблялися відповідно для середніх значень показників і для найгірших (максимальних або мінімальних) значень. Порівняння результатів роботи класифікатора 3 прикладом, наведеним в [8], дозволило встановити $100 \%$ відповідність отриманих результатів за допомогою модуля.

Після розроблення класифікаторів для середніх і найгірших значень окремих показників було розроблено відповідні класифікатори для відносних одиниць якості води з виведенням характеристик одержаних класів і підкласів якості води. Приклад програмної реалізації алгоритму класифікатора в середовищі MathCAD наведено на рисунку 2.

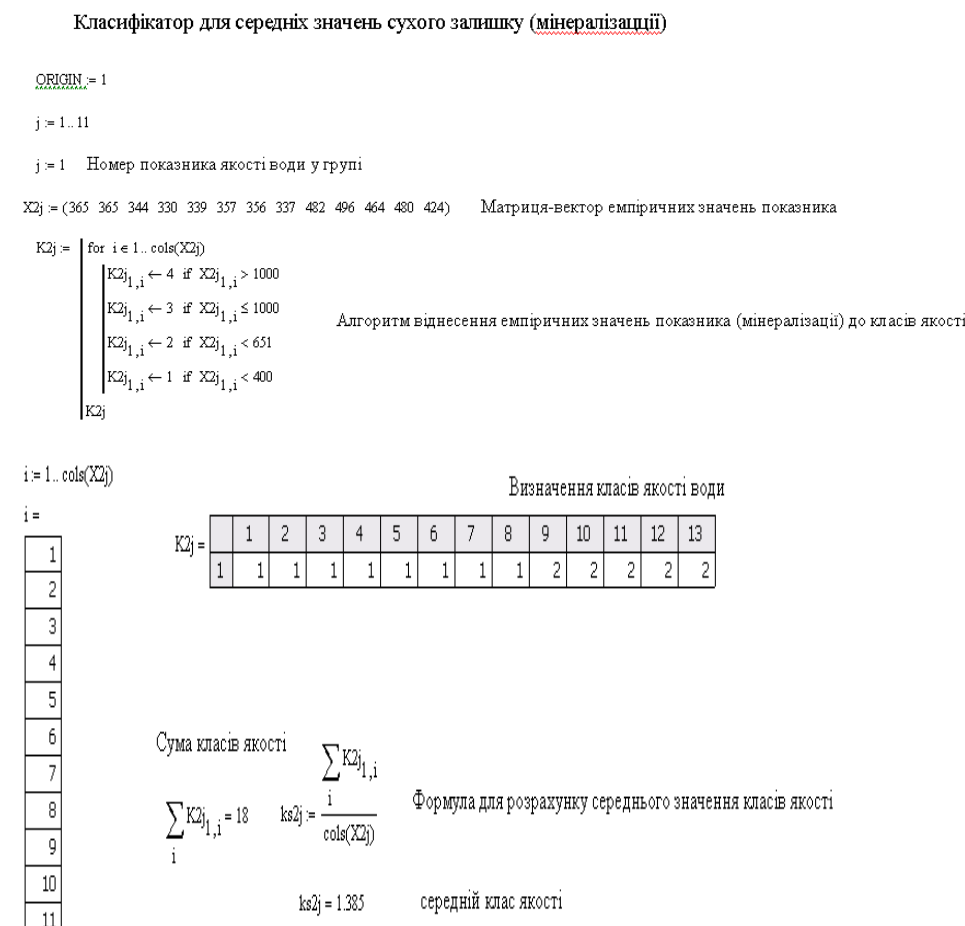


Реалізація класифікаторів у середовищі дозволяє повністю автоматизувати процес, усунути вплив людського фактора і вивести результати щодо якості води, прийнятні для систем підтримки наукових досліджень. Окрім цього, реалізація алгоритмів класифікації в МathCAD забезпечує процедури програмування наочним і зрозумілим інтерфейсом, що $є$ актуальним у їх відлагодженні, оптимізації і перевірці правильності роботи.

Окрім використання розробленого модуля АСПНД, студенти екологи залучаються до самостійного створення аналогічних модулів при вирішенні актуальних екологічних задач. У математичному процесорі функціональним $\epsilon$ розширений набір функцій, які забезпечують зчитування файлів (текстових, електронних таблиць, тощо) з даними для оброблення, а також експорту одержаних результатів до окремого файлу.

Отже, у випадку реалізації модуля автоматизованої системи в зазначеному програмному середовищі, завдання користувача максимально спрощуються у проведенні процедури визначення якості води за стандартизованими методиками. Зокрема, для цього достатньо ввести дані для аналізу в окремий файл і одержати результат аналізу. При цьому можуть бути виведеними, як кінцеві результати, так і проміжні у вигляді класів якості води за значеннями окремих показників. Використання такого модуля АСПНД у розрізі визначених навчальних курсів у науково-дослідній роботі дозволить підвищити ефективність набуття фахових знань та вмінь, наблизити теоретичні знання до практичної реалізації, продемонструвати ефективність застосування інформаційних технологій та математичних методів у фаховій діяльності, активізувати студентські наукові дослідження шляхом зменшення часу і кількості обчислювальних процедур для оброблення експериментальних даних.

Зазначено, що одним із напрямів підвищення якості фахової підготовки майбутніх екологів, їх конкурентоспроможності та підготовленість до роботи у природоохоронній сфері та Державній системі моніторингу довкілля $\epsilon$ застосування автоматизованих систем підтримки наукових досліджень. Модульний принцип побудови таких систем забезпечує їх упровадження до змісту окремих навчальних курсів та актуальні напрями наукових досліджень в екології.

Актуальними напрямами подальшого розроблення є: створення модулів АСПНД, призначених для використання в навчальних курсах та студентській науково-дослідній роботі, з урахуванням і подальшим розвитком окреслених напрямів актуальних досліджень в екології.

\section{Література}

1. Гаріна С. М. Оптимізація алгоритмів оцінювання якості води джерел сільськогосподарського водопостачання: [монографія] / С. М. Гаріна, Р. О. Тарасенко, В. А. Копілевич. - К. : ТОВ «Алефа», 2011. 244 с. 2. Лисьев Г. А. Автоматизированная система поддержки научных исследований в области экономики образования / Г. А. Лисьев // Интеллектуальные системы (AIS'08) и Интеллектуальные CAПР (CAD’08): труды VIII Междунар. науч.-техн. конф. (Россия, Геленджик-Дивноморское, 3-9 сент. 2008 г.). - М. : Физматлит, 2008. - Т.1. - С. 280 - 285. 3. Семенова И. И. Развитие автоматизированных систем поддержки научных исследований / И. И. Семенова // Современные информационные технологии и ИТ-образование: сборник трудов IV Междунар. науч. - практ. конф. [Электронный ресурс]. - Режим доступа: http://2009.itedu.ru/docs/Sekzii 45/24r Semenova 1257006355734795.doc (дата обращения: 6.01.2010). 4. Измайлов В. Г. Компьютерная поддержка подготовки социологов и проведения полевых исследований в социологии / В. Г. Измайлов, М. Ю. Озерова, А. Л. Трейбач // Математика. Компьютер. Образование: сборник трудов XVI Междунар. конф. (г. Пущино, Московская область, 19-24 янв. 2009 г.); под общей ред. Г. Ю. Ризниченко. Ижевск : Научно-изд. центр «Регулярная и хаотическая динамика», 2009. - С. 189-198. 5. Гаврилов С. Е. Распределенная информационная система поддержки научно-образовательного процесса с обеспечением удаленного доступа к информационным и техническим ресурсам / С. Е. Гаврилов, Е. Д. Жиганов, С. А. Кипрушкин, С. Ю. Курсков, А. Д. Хахаев // Университеты в образовательном пространстве региона: опыт, традиции и инновации: материалы докладов II Межвуз. науч.-метод. конф. (Петрозаводск, 26-28 мар. 2003 г.). Петрозаводск : Изд. ПетрГУ, 2003. - С 46 - 47. б. Фомичев Н. И. Автоматизированные системы научных исследований: [учеб. пособ. для студ. физ. ф-та] / Н. И. Фомичев. - Ярославль : Ред.-издат. отдел ЯГУ, 2001. 112 с. 7. Виноградова Н. А. Научно-методические основы построения АСНИ / Н. А. Виноградова, А. А. Есюткин, Г. Ф. Филаретов. - М. : МЭИ, 1989. - 84 с. 8. ДСТУ 4808:2007. Джерела централізованого питного водопостачання. Гігієнічні та екологічні вимоги щодо якості води і правила вибирання. - К. : Держспоживстандарт України, 2007. - 36 с. 